DOI 10.18551/rjoas.2021-11.13

\title{
EASY ACCESS TO PUBLIC SERVICES THROUGH DIGITAL VILLAGE
}

\author{
Sara I Made*, Saputra Komang Adi Kurniawan \\ Faculty of Economics and Business, Warmadewa University, Indonesia \\ *E-mail: madesara022@gmail.com
}

\begin{abstract}
This study prioritizes an approach to the community with the aim of obtaining information and data related to the development of digital villages in Bali Province. The digital village initiated by the central government is a continuation of the desire that the village should become an independent village. Various steps have been taken by the village government such as realizing a tourist village and a digital village, even the synergy of the two. This research was conducted in tourism and digital villages in Bali. Data and information obtained by in-depth interview techniques. The information obtained is managed and analyzed to obtain adequate results. Informants in this study came from various circles of society such as village heads, village consultants, academics and local communities. The result of this research is that in Bali, Digital villages have developed in several areas such as Badung, Tabanan and Buleleng Regencies. The development of this digital village is mostly focused on community services and village governance systems. However, various problems are also faced by these villages such as the need for internet network infrastructure support and quality human resources in creating digital villages. In addition, the synergy of official villages and traditional villages is also needed in supporting the implementation of digital villages. Various problems are also faced by these villages such as the need for internet network infrastructure support and quality human resources in creating digital villages. In addition, the synergy of official villages and traditional villages is also needed in supporting the implementation of digital villages. Various problems are also faced by these villages such as the need for internet network infrastructure support and quality human resources in creating digital villages. In addition, the synergy of official villages and traditional villages is also needed in supporting the implementation of digital villages.
\end{abstract}

\section{KEY WORDS}

Digital village, public services, tourist village, village governance.

The development gap is something that is still happening in Indonesia. The gap occurs between regions as well as between cities and villages. The gap between cities and villages also occurs in terms of information and communication technology. In the long term, the development gap between regions can have a negative impact on the social life of the community so that it becomes a serious problem that must be resolved in the future. The gap between regions can be seen from the 122 districts which are underdeveloped areas (Saputra et al., 2021). The gap between urban and rural areas can be seen from the rapid pace of urbanization in recent years. Currently, the rate of urbanization in the village is 1.2 percent annually. The development gap between urban and rural areas cannot be separated from the impact of the uneven distribution of demographics and economic capacity as well as the gap in the availability of adequate infrastructure, including the gap in information and communication technology (Xu et al., 2018). According to the Ministry of Communication and Information of the Republic of Indonesia, the number of villages that have not been touched by information and communication technology is around 40 percent in 2017-2018. These gaps make it difficult for the village to develop. According to Indonesian statistics data, the number of villages with underdeveloped status still dominates the total number of villages in Indonesia. the number of villages that have not been touched by information and communication technology is around 40 percent in 2017-2018. These gaps make it difficult for the village to develop. According to Indonesian statistics data, the number of villages with underdeveloped status still dominates the total number of villages in Indonesia. The number 
of villages that have not been touched by information and communication technology is around 40 percent in 2017-2018. These gaps make it difficult for the village to develop (Biswas et al., 2019). According to Indonesian statistics data, the number of villages with underdeveloped status still dominates the total number of villages in Indonesia.

The digital village is one of the programs to reduce the gap in the flow of information that occurs in the village (Peng et al., 2021). The concept of a digital village is the use of integrated information and communication technology in public services and economic activities.Digital village development is carried out to drive the economy of rural communities, through empowering rural communities that can provide economic benefits (Şerbu, 2014). Therefore, the government continues to increase the acceleration of access and development of digital infrastructure to serve the public quickly and efficiently.Digital services will encourage the improvement of public services in villages and make it easier for village officials to evaluate and improve services with a database that will be owned later (Peng et al., 2021). In addition, digital villages will also facilitate the use of village financial system applications so that village financial management including village funds can be more transparent and accountable. In the economic context, digital villages can be used as a catalyst for improving village economic performance and empowering rural communities (Chamidah et al., 2020). In the digital village, it is planned to have a website and social media accounts for promotions and news, e-commerce systems and applications that are in accordance with the character and economic potential of each village (Mariyatni et al., 2020; Saputra, Rumini, et al., 2020).

Through the application of technology and information in digital villages, it is hoped that productivity can increase following the success stories of other villages in using the internet, for example Majasari village in Indramayu Regency (Saputra, Rumini, et al., 2020). With the internet, the people in the village get improvements in their way of farming and organic farming. Majasari Village applies feed processing technology from agricultural waste to provide animal feed. The livestock waste is then used as fertilizer on agricultural land. Majasari village since a few years ago has switched to organic farming (Saputra, Anggiriawan, et al., 2019; Saputra et al., 2021). With the existence of the internet, agricultural and livestock products in Majasari village can be marketed all over the country so as to improve the village economy. This makes the village of Majasari successful in reducing the poverty rate to 8,24 percent and was ranked as one of the best villages in 2016 . Furthermore, in order to facilitate community services, currently 46 villages in Badung Regency use digital or information technology-based systems (Kamath, 2008). For example, a village in Badung, Punggul Village, has become a national digital village pilot. Through digital villageln this case, the Population Administration Information System, Village and SubDistrict Administration Information System, Geographic Information System, and Village Government Information System can be easily accessed. Badung has also been supported by adequate infrastructure by providing free wifi starting at schools, health centers, village offices, to the banjar hall.

\section{LITERATURE REVIEW}

According to Law Number 25 of 2009 concerning Public Services, public services are activities or series of activities in the context of fulfilling service needs in accordance with laws and regulations for every citizen and resident of goods, services, and/or administrative services provided by public service providers. The word "goods, services and administrative services" in the explanation section is considered clear, but actually the meaning of "goods" is not goods that can be traded by humans on a daily basis but are public goods that are provided by the government (Perkins, 2011). The implementation of public services in Indonesia is supervised by an independent institution that is free from the executive area

called the Ombudsman of the Republic of Indonesia (Chhetri et al., 2012). The Ombudsman's authority in supervising the implementation of public services as stated in Article 1 of Law no. 37 of 2008 that the Ombudsman is a state institution that has the authority to oversee the implementation of public services, both those organized by state and 
government officials, including those held by State-Owned Enterprises, Regional-Owned Enterprises and others as well as private entities or individuals who are assigned the task of providing certain public services (C. I. R. S. Dewi et al., 2019; Suebvises, 2018). which part or all of the funds are sourced from the state and/or regional budgets of revenues and expenditures .

Public service is a series of activities in the context of fulfilling service needs in accordance with statutory regulations for every citizen and resident of goods, services or administrative services as defined in Law no. 25 of 2009 concerning Public Services. Therefore, the government was formed, among others, to promote the general welfare and educate the nation's life (Korhonen et al., 2021). This means that the state is obliged to meet the needs of every citizen through a government system that supports the creation of excellent public service delivery in order to fulfill the basic needs and civil rights of every citizen for public goods, public services, and administrative services (Harrison \& Donnelly, 2011).

Currently, public services are faced with changes in various fields of social, national and state life. Therefore, the government is required to be ready to respond to public expectations and global challenges triggered by changes and advances, especially in the field of technology. The world has changed where activities are carried out by utilizing digital technology. Future challenges related to public services are increasingly interesting to discuss because people's lives have changed greatly where they demand services that are faster, cheaper, easier and transparent (Papachristou \& Papachristou, 2014). People's lives are increasingly difficult to be separated from technology. They will be restless if they are not connected to other people. Even today, a person will be very nervous if his smartphone is lost or left behind (Jayawarsa et al., 2021).

The development of technology always makes people connect with each other easily and it is hoped that public services can be carried out by utilizing these technological developments. However, offline services in the office are not necessarily abandoned and must be integrated between on-line and off-line services (Boyne, 2003). Therefore, it is no longer relevant to view the community as an object of service with a convoluted process and an outdated mindset that "If you can make it difficult, why make it easier?". The state must be closer to the community and able to provide comfort and stimulate the community to be more innovative, creative, productive and make a real contribution to national development (Light, 2001).

The development of information technology provides challenges in rural economic development. Villages are required to be able to adapt to technological advances by reducing the digital divide through the development of digital villages. The development of this digital village can encourage the progress of all fields in the village such as education, the economy, tourism and services to the community (Atieno \& Moturi, 2014). In the field of education, this digital technology can be utilized in the teaching and learning process, so that teachers and students become competent and advanced human resources. This digital village can also encourage Village-Owned Enterprises to promote their local products using e-commerce channels or market places (Sara et al., 2021). Likewise with tourism, with digital villages, it is hoped that tourism potential will be more easily introduced to the wider community. In turn, people's welfare will increase through digital innovation. With the digital village, it is also hoped that all information and population services will be served easily (Saputra, Jayawarsa, et al., 2019). To support this digital village, adequate facilities and infrastructure are needed, such as an internet network in the village, human resources for digital village managers, as well as active support from the Village, District and Regency Governments (Sara et al., 2020).

\section{METHODS OF RESEARCH}

The key to gathering information is in the interview process. The interviewer's ability to interact with the respondents also determines the quality of the information collected. The interviewer has the main task of enabling the respondent to participate in the survey and 
recording information from the respondent. While the interview is a special way in a structured conversation setting, where each interviewer and respondent has a limited role to play. The influence of the interviewer on the success of a survey can be seen in conditions, namely the interviewer plays a major role in the response rate obtained. the interviewer is responsible for initiating and motivating respondents. the interviewer can handle the standard and unbiased parts of the interview interaction and question and answer process (Saputra et al., 2021; Saputra \& Anggiriawan, 2021).

This in-depth interview technique, in principle, is an interview where the researcher and the respondent meet face-to-face in the interview conducted. Researchers expect to obtain information from respondents regarding a problem under study, which cannot be revealed through the use of questionnaire techniques. Therefore, in conducting in-depth interviews, the questions that will be asked to the respondents cannot be formulated with certainty beforehand, but the questions will depend a lot on the ability and experience of the researcher to develop follow-up questions according to the respondents' answers (Tresna \& Nirmalasari, 2018).

\section{RESULTS AND DISCUSSION}

Synergy of Local Culture with Digital-Based Community Service. The era of digital transformation should be able to increase the development and development of potential. One of them is by inviting the younger generation to create a digital village. The increasing trend of using information technology seems to require people to adapt in their daily lives, especially rural communities (Saputra et al., 2021). The concept of a digital village is important as a solution to increase community participation to be more empowered in implementing technology in village life. Smart government related to the use of communication technology in public services (Bontis, 1998; Zhang, 2019). Smart economics related to optimizing village products with internet research. Smart mobility and environment related to information outreach infrastructure. Smart people related to people's skills in finding information as needed. Then there is smart living and tourism related to the environment and regional potential. To support this, digital skills need to be owned by the community in developing the economy and providing village information access services. Of course, you have to consider community empowerment strategies in digital villages (Harrison \& Donnelly, 2011; Rahmiati et al., 2020).

"In the context of the combination of digitalization with local community culture, especially in Bali which has a strong culture and is highly preserved, this requires synergy between the local culture of the community and village digitization. The local culture that guides the lives of the Balinese people is Tri Hita Karana, which has a wide reach in village development and community life. the development of a digital village as long as it does not violate the norms of Balinese society, then it can be done. For example, in terms of preparing or managing village finances by paying attention to the relationship between humans and God, fellow humans and the environment. All these things must go hand in hand and in harmony. Do not let the digitization of villages destroy the existing order in society" (Interview with the Village Head in Buleleng Regency, Bali).

Based on the statement, that the concept of digitalization and local culture must go hand in hand, complement each other and should not overlap so as to cause confusion in the community (L. K. Y. Dewi, 2014; Wardana et al., 2021). The provision of excellent public services is a priority, by making it easier for the community to get access to services and providing socialization and knowledge to the community through continuous education so that human resources in the village become superior and of high quality (Kim \& Todorovic, 2013; Mariyatni et al., 2020).

The application of this digital village allows for transparency, acceleration of information and public services, ease of access, promotion of human resources and the village economy, as well as increasing community knowledge (Marwoto, 2016; Nahapiet \& Ghoshal, 1998). Transparency of digitization is related to the transparency of information, finance, and village programs. Promotion of village potential can be through blogs or websites. Human resource 
training can also improve the agricultural and multimedia sectors. It is hoped that a number of villages in Indonesia can apply this concept with the support of a number of parties (Saputra, Subroto, et al., 2020). So that technological facilities and village potential are growing (Rahmat et al., 2018). There must be cooperation between youth, government, private sector, and corporations to improve village culture, economy and politics. One of them brings up village creators. So that the ultimate goal of efficient village community welfare can be achieved (Sara et al., 2020).

The Challenge of Realizing a Digital Village. Digital village is a concept that requires the availability of adequate information and communication networks. However, there are still many areas in Indonesia where the condition of information technology is still low or even non-existent. According to data from the Village Potential of the Central Statistics Agency in 2018, there are still around 62 percent of villages that do not have BTS (Base Transceiver Station) (Berghel, 2000). In terms of cell phone signal strength and internet signal strength, there are still many villages whose signal strength is weak or even non-existent, namely 34 percent for telephone signals and 21.6 percent for internet signals (Cunningham \& Crandall, 2014). This is a challenge in itself in forming a digital village. Another challenge to realize digital villages is that it requires substantial funding support.Digital village development is carried out to drive the economy of rural communities, through empowering rural communities that can provide economic benefits. For this reason, the government continues to increase the acceleration of access and development of digital infrastructure to serve the public quickly and efficiently (Canevez et al., 2020).

"To form a digital village requires infrastructure collaboration with the government, both district, provincial and central governments. Meanwhile, the devices and applications are provided by the local government by relying on the Regional Revenue and Expenditure Budget. The provision of these devices and applications requires relatively large funds. On the other hand, there are still many regions (especially districts) that have low financial capacity and are still very dependent on balancing funds from the central government. In order to minimize temporary funds, a digital center can be established in the village that can be accessed by all communities so that their use can be controlled" (Interview with village consultant).

This statement means that the challenges faced by villages in forming digital villages are infrastructure, either in the form of internet signal coverage or other infrastructure to support digital villages (Rusdan, 2019). Good cooperation must be established between the central, regional, district and village governments in all forms of supporting infrastructure. The next challenge is the availability of human resources capable of managing various information technology-based services. It is undeniable that in villages there are still village officials and people who are not yet literate with the internet and technology (Di Salvo et al., 2017; International Finance Corporation, 2010).

In addition, the village community still holds a strong culture which may be an obstacle in the entry of something new from the outside such as the internet. The existence of negative content from internet access is also a challenge in the procurement of digital villages (Canevez et al., 2020). Thus, socialization, assistance, and digital literacy are needed for human resources and rural communities that are adapted to the characteristics and culture of the community (Berghel, 2000). Currently there is assistance from information technology volunteers for digital villages, but the number is limited so that the involvement of other parties is needed in assistance and digital literacy (Cunningham \& Crandall, 2014). To realize an optimal digital village, various steps are needed from the government, both the central government and local governments. First, There is a need for support and cooperation from various parties in terms of funding, mentoring, training and digital literacy from the central government, the private sector, academics and the community. Second, the synergy with the integrated broadband village program by focusing on developing digital applications, especially in villages with the same characteristics (Cheng \& Zhang, 2021).

Digital Village Development in Bali. Investing in tourism, especially in remote areas or even on the edge of the country, can be an alternative for equitable distribution of welfare for the people of Indonesia. The exotica of tourist destinations in various parts of Indonesia, 
there are still many that have not been exposed and seem to be drowning under the pretext of remoteness or lack of information from the outside world to find out. In fact, one of the steps to raise the potential of villages with various traditional, cultural and panoramic features that exist in various parts of Indonesia, even in the outskirts of the country, can be done by implementing a digital 'smart village' (Somwanshi et al., 2016; Rusdan, 2019; Sutriadi, 2018).

Investment in tourism, by formatting traditional villages that are often found in Indonesia into smart villages, can be an innovative breakthrough in the context of liberating a village from the confines of remoteness. Moreover, investment in the tourism sector has many advantages. One of them, can absorb local workers from local villages, so it is hoped that the level of the regional economy can increase (Mihalič et al., 2012; Turner \& Guilding, 2014). This digital village aims to drive the economy of rural communities, through empowering rural communities that can provide economic benefits (Amoako-Gyampah \& Acquaah, 2008; Nik Abdullah, 2020). This digital village is to go to a precision village based on digital data.digital villageis a solution for villages in community empowerment through the use of digital technology and the internet in developing the potential of rural communities, marketing and accelerating access and information services. Inequality of digitizing rural communitieswith urban areas is one of the problems in Indonesia (Sah, 2016; Sara et al., 2020). Later, all public services in the village will be digitized, with an internet connection, village communities can use social media to promote and introduce superior products in their area (De Jong \& Sauerwein, 2021).

Digital Village Program inKerambitan District,Tabanan Regencycan't walk yet. Many factors are the cause. One of them is a refocused budget for handling Covid-19. Though the developmentdigital villagehas tremendous benefits, especially the empowerment of rural communities. In Tabanan, only a few villages have implemented it. As in Tabanan District, there are only three villages, namely Dauh Peken Village, Delod Peken, and Gubug Village. In this village, all forms of administrative services in the village such as services for business certificates, domicile statements, certificates of incapacity, making family cards, identity cards and others are done digitally.

"The problems that occur in the village at this time are the lack of knowledge and lack of community involvement in promoting tourism potential and the absence of supporting facilities to market tour packages managed by tourism awareness groups in the village. From these problems, in this community service activity, 2 aspects will be considered, including the information technology aspect by creating a village website, a Village Owned Enterprise website, a tour package sales website, and making Augmented Reality applications. In an effort to improve the promotion and marketing of tour packages, there will be socialization of the use of websites and applications that have been developed, training on managing websites and applications, as well as SEO (Search Engine Optimization) and Google My Business technology optimization training for tour package management groups. After making the website and application, then socialization activities with the community are carried out. This activity is carried out by providing information to partner communities about the use of websites and applications that have been developed to support the development of tourism potential and increase community involvement in the management of tourist villages in the village. This training activity is specifically aimed at the tourism village management group in the village. This tourist village management group serves as an administrator by managing all content on the website and application. This training is also aimed at the tourism village management group as an effort to increase the promotion of villages and tourist attractions through the use of SEO technology and Google My Business on the website that has been developed. The achievement targets in this community partnership program activity are increasing partner skills by $80 \%$, increasing partner knowledge by $90 \%$ " (Interview with one of the academics who are doing community service in a Tourism Village in Bali)

Based on this statement, the juxtaposition of tourist villages and digital villages prioritizes digital conceptions in every tourism village development. a village must also develop sustainable tourism that is adapted to the capacity of the village's human resources. The management of a village must be determined by the villagers themselves. The principle 
of managing a tourism village is based on humans, the important thing is that the society supports it, the community supports it. Because the principle of village development is to make villagers the subject of development. In the sense that it is the villagers who are the main subject of the development of the tourist village (Chamidah et al., 2020; Sara et al., 2020). One of the unique things that can be highlighted from these villages include beaches, mountains, and the culture of the village (Saputra, Sara, et al., 2019; Sara et al., 2020).

\section{CONCLUSION}

It should be noted that the role of rural areas is quite important for national stability. The government itself has provided support in realizing independent rural areas through policies to accelerate and improve the quality of infrastructure in villages and human resources. In Bali Province, especially Tabanan Regency and Buleleng Regency, since 2016 it has been designated as a cultured and food-sovereign natural environment area. And in 2018, Buleleng Regency was designated as a Bali Ageng village. The commitment is that this area is the basis for the preservation of customs and food sovereignty. In Bali Province, previously there were 27 independent villages, 228 developed villages, 278 developing villages, 78 underdeveloped villages, and 4 villages still lagging behind. Since 2015 many programs have targeted villages in Bali. Until this 2019, there are 142 developed villages and none are left behind. With the digital village program, currently some villages on the island of Bali have implemented it by cooperating with the private sector as well as the central and regional governments. digital villages in Tabanan and Badung districts are pilot villages nationally. And until now, the digital village is growing to other villages. The most visible characteristics are the development of an internet-based or computerized public service system. For example in the service of making identity cards and information on recipients of social assistance. Announcements as a form of transparency have also been delivered on a digital basis. All villages already have their own village websites, and by utilizing today's technology, small business units in the village can market their products outside the region. This kind of development must be supported both in terms of infrastructure, human resources and adequate knowledge. This digital village synergizes with the tourism village program and makes the village an independent village, with the main goals being the welfare of the village community, the development of Indonesia from the village, and superior and quality village communities.

\section{REFERENCES}

1. Amoako-Gyampah, K., \& Acquaah, M. (2008). Manufacturing strategy, competitive strategy and firm performance: An empirical study in a developing economy environment. International Journal of Production Economics. https://doi.org/10.1016/j.ijpe.2007.02.030.

2. Atieno, L. V., \& Moturi, C. A. (2014). Implementation of Digital Village Projects in Developing Countries-Case of Kenya.

3. Berghel, H. (2000). Digital village: predatory disintermediation. Communications of the ACM, 43(5), 23-29.

4. Biswas, R., Jana, A., Arya, K., \& Ramamritham, K. (2019). A good-governance framework for urban management. Journal of Urban Management, 8(2), 225-236. https://doi.org/10.1016/j.jum.2018.12.009.

5. Bontis, N. (1998). Mapping the human capital management research trends using bibliometric analysis. Management Decision, 32(6), 63-76.

6. Boyne, G. A. (2003). What is public service improvement?. Public administration, 81(2), 211-227.

7. Canevez, R., Maitland, C., \& Rantanen, M. (2020). A Dynamic Perspective of Internet Service Provider Adoption of Emergent Network Technology: A Case Study of Tribal Digital Village. Journal of Information Policy, 10, 83-122.

8. Chamidah, N., Putra, A. H. P. K., Mansur, D. M., \& Guntoro, B. (2020). Penta helix Element Synergy as an Effort to Develop Tourism Villages in Indonesia. Jurnal 
Manajemen Bisnis, 8(1), 01-22. https://doi.org/10.33096/jmb.v8i1.625.

9. Cheng, F., \& Zhang, J. (2021). Research on rain slope stability and digital village construction in mountainous areas based on remote sensing images. Arabian Journal of Geosciences, 14(18), 1-15.

10. Chhetri, B. B. K., Lund, J. F., \& Nielsen, O. J. (2012). The public finance potential of community forestry in Nepal. Ecological Economics, 73, 113-121. https://doi.org/10.1016/j.ecolecon.2011.09.023.

11. Cunningham, C. M., \& Crandall, H. M. (2014). Social media for social justice: Cyberfeminism in the digital village. In Feminist Community Engagement (pp. 75-91). Palgrave Macmillan, New York.

12. De Jong, T. U., \& Sauerwein, T. (2021). State-owned minerals, village-owned land: How a shared property rights framework helped formalize artisanal diamond miners in Côte d'Ivoire between 1986 and 2016. Resources Policy, 70, 101920. https://doi.org/10.1016/j.resourpol.2020.101920.

13. Dewi, C. I. R. S., Surya, L. P. L. S., \& Saputra, K. A. K. (2019). Pengaruh Kepemilikan Manajerial dan Kepemilikan Institusional Terhadap Pemilihan Kantor Akuntan Publik pada Perusahaan Pertambangan yang Terdaftar di Bursa Efek Indonesia. DIALEKTIKA: Jurnal Ekonomi Dan IImu Sosial, 4(1), 26-33. https://doi.org/10.36636/dialektika.v4i1.283

14. Dewi, L. K. Y. (2014). Modeling the Relationships between Tourism Sustainable Factor in the Traditional Village of Pancasari. Procedia - Social and Behavioral Sciences, 135, 5763. https://doi.org/10.1016/j.sbspro.2014.07.325.

15. Di Salvo, A. L. A., Agostinho, F., Almeida, C. M. V. B., \& Giannetti, B. F. (2017). Can cloud computing be labeled as "green"? Insights under an environmental accounting perspective. Renewable and Sustainable Energy Reviews, 69(November 2016), 514526. https://doi.org/10.1016/j.rser.2016.11.153.

16. Harrison, C., \& Donnelly, I. A. (2011). A theory of smart cities. 55th Annual Meeting of the International Society for the Systems Sciences 2011.

17. International Finance Corporation. (2010). Mobile Banking in Indonesia: Assessing the Market Potential for Mobile Technology to Extend Banking to the Unbanked and Underbanked - Final Report. In International Finance Corporation (pp. 1-54).

18. Jayawarsa, A. K., Wulandari, I. G. A. A., Saputra, K. A. K., \& Saputri, N. M. M. D. (2021). Public financial deposits in state owned banks: from an inflation perspective and bank indonesia interest rates. International Journal of Business, Economics and Law, 24(1), $105-112$.

19. Kamath, B. (2008). Intellectual capital disclosure in India: content analysis of "TecK" firms. Journal of Human Resource Costing \& Accounting, 12(3), 213-224. https://doi.org/10.1108/14013380810919859.

20. Kim, J. T., \& Todorovic, M. S. (2013). Towards sustainability index for healthy buildings Via intrinsic thermodynamics, green accounting and harmony. Energy and Buildings, 62, 627-637. https://doi.org/10.1016/j.enbuild.2013.03.009.

21. Korhonen, T., Selos, E., Laine, T., \& Suomala, P. (2021). Exploring the programmability of management accounting work for increasing automation: an interventionist case study. Accounting, Auditing and Accountability Journal, 34(2), 253-280. https://doi.org/10.1108/AAAJ-12-2016-2809.

22. Light, P. C. (2001). The new public service. Brookings Institution Press.

23. Mariyatni, N. P. S., Senimantara, I. N., Juniariani, N. M. R., Jayawarsa, A. A. K., \& Saputra, K. A. K. (2020). Effectiveness of village financial information system implementation. Journal of Advanced Research in Dynamical and Control Systems, 12(7), 8-16. https://doi.org/10.5373/JARDCS/V12/7/20201978.

24. Marwoto. (2016). Spiritual Phenomena in the Town of Demak. Procedia - Social and Behavioral Sciences, 227(November 2015), 451-457. https://doi.org/10.1016/j.sbspro.2016.06.100.

25. Mihalič, T., Žabkar, V., \& Cvelbar, L. K. (2012). A hotel sustainability business model: Evidence from Slovenia. Journal of Sustainable Tourism, 20(5), 701-719. https://doi.org/10.1080/09669582.2011.632092. 
26. Nahapiet, J., \& Ghoshal, S. (1998). Social Capital, Intellectual Capital, And The Organizational Advantage. Academy of Managemeni Review, 23(2), 242-266.

27. Nik Abdullah, N. H. (2020). Assessing Strategic Management Accounting Practices in Public Interest Companies in Malaysia. Indonesian Journal of Economics, Social, and Humanities, 2(1), 13-25. https://doi.org/10.31258/ijesh.2.1.13-25.

28. Papachristou, G. K., \& Papachristou, M. K. (2014). The worthiness of corporate governance in public sector the case of public healthcare sector in Greece. Corporate Ownership and Control, 12(1CONT5), 490-500. https://doi.org/10.22495/cocv12i1c5p4.

29. Peng, C., Ma, B., \& Zhang, C. (2021). Poverty alleviation through e-commerce: Village involvement and demonstration policies in rural China. Journal of Integrative Agriculture, 20(4), 998-1011. https://doi.org/10.1016/S2095-3119(20)63422-0.

30. Perkins, H. A. (2011). Gramsci in green: Neoliberal hegemony through urban forestry and the potential for a political ecology of praxis. Geoforum, 42(5), 558-566. https://doi.org/10.1016/j.geoforum.2011.05.001.

31. Rahmat, A., Izzudin, A., \& Kudir, S. (2018). Menguatkan Pembangunan Desa Berkelanjutan: Perspektif Implementasi UU Desa No. 6 Tahun 2014 di Kabupaten Bantul. Jurnal Kesejahteraan Sosial, 2(02), 88-99. https://doi.org/10.31326/jks.v2i02.161.

32. Rahmiati, F., Othman, N. A., \& Tahir, M. N. H. (2020). Examining the trip experience on competitive advantage creation in tourism. International Journal of Economics and Business Administration, 8(1), 15-30. https://doi.org/10.35808/ijeba/405.

33. Rusdan, M. (2019). Design of wireless network system for digital village using wireless distribution system. Journal of Informatics, Information System, Software Engineering and Applications (INISTA), 1(2), 51-59.

34. Sah, B. P. (2016). Geo-enabled Decision Support System for Potential Clean Energy Mix for Bali, Indonesia. Energy Procedia, 103(April), 333-338. https://doi.org/10.1016/j.egypro.2016.11.295.

35. Saputra, K. A. K., \& Anggiriawan, P. B. (2021). Accounting, Auditing And Corruption In Kautilya's Arthasastra Perspective And Psychogenetic Hindu: A Theoritical Review. South East Asia Journal of Contemporary Business, Economics and Law, 24(2), 67-72.

36. Saputra, K. A. K., Anggiriawan, P. B., Sanjaya, I. K. P. W., Jayanti, L. G. P. S. E., \& Manurung, D. T. H. (2019). The Role of Human Resource Accounting and the Synergy of Village Government in Village Fund Management. Journal of Advance Research in Dynamical and Control System, 11(11), 303-309. https://doi.org/10.5373/JARDCS/V11111/20193200.

37. Saputra, K. A. K., Jayawarsa, A. A. K., \& Atmadja, A. T. (2019). Resurrection as a fading implication of accountability in financial management for village credit institution. International Journal of Business, Economics and Law, 19(5), 258-268.

38. Saputra, K. A. K., Manurung, D. T. H., Rachmawati, L., Siskawati, E., \& Genta, F. K. (2021). Combining the Concept of Green Accounting With the Regulation of Prohibition of Disposable Plastic Use. International Journal of Energy Economics and Policy, 11(4), 8490. https://doi.org/10.32479/ijeep.10087.

39. Saputra, K. A. K., Rumini, D. A., Suarka, I. B. K., \& Jayawarsa, A. A. K. (2020). Quality Asset Management and Asset Identification to Increase Village Income. Productivity Management, 25(4), 42-51.

40. Saputra, K. A. K., Sara, I. M., Jayawarsa, A. A. K., \& Pratama, I. G. S. (2019). Management of Village Original Income in The Perspective of Rural Economic Development. International Journal of Advances in Social and Economics, 1(2), 52. https://doi.org/10.33122/ijase.v1i2.40.

41. Saputra, K. A. K., Subroto, B., Rahman, A. F., \& Saraswati, E. (2020). Issues of morality and whistleblowing in short prevention accounting. International Journal of Innovation, Creativity and Change, 12(3), 77-88.

42. Sara, I. M., Jayawarsa, A. A. K., \& Saputra, K. A. K. (2021). Rural Assets Administration and Establishment of Village-Owned Enterprises for the Enhancement of Rural Economy. Jurnal Bina Praja, 13(1), 81-91. https://doi.org/https://doi.org/10.21787/ jbp.13.2021.8191. 
43. Sara, I. M., Saputra, K. A. K., \& Utama, I. W. K. J. (2020). Improving Economic Development Through The Establishment Of Village- Business Enterprises. Journal of Advanced Research in Dynamical and Control Systems, 12(06), 3032-3039. https://doi.org/10.5373/JARDCS/V12I6/S20201269.

44. Şerbu, R. S. (2014). An Interdisciplinary Approach to the Significance of Digital Economy for Competitiveness in Romanian Rural Area Through E-agriculture. Procedia Economics and Finance, 16(May), 13-17. https://doi.org/10.1016/s2212-5671(14)00768-0.

45. Somwanshi, R., Shindepatil, U., Tule, D., Mankar, A., Ingle, N., Rajamanya, G. B. D. V., \& Deshmukh, A. (2016). Study and development of village as a smart village. International Journal of Scientific \& Engineering Research, 7(6), 395-408.

46. Suebvises, P. (2018). Social capital, citizen participation in public administration, and public sector performance in Thailand. World Development, 109, 236-248. https://doi.org/10.1016/j.worlddev.2018.05.007.

47. Sutriadi, R. (2018, November). Defining smart city, smart region, smart village, and technopolis as an innovative concept in indonesia's urban and regional development themes to reach sustainability. In IOP Conference Series: Earth and Environmental Science (Vol. 202, No. 1, p. 012047). IOP Publishing.

48. Tresna, P. W., \& Nirmalasari, H. (2018). Sustainable Competitive Advantage Strategies of Tourism Products in Pangandaran District. Review of Integrative Business and Economics Research, 7(3), 34-47.

49. Turner, M. J., \& Guilding, C. (2014). An investigation of Australian and New Zealand hotel ownership. Journal of Hospitality and Tourism Management, 21, 76-89. https://doi.org/10.1016/j.jhtm.2014.08.003.

50. Wardana, I. M., Sukaatmadja, I. P. G., Yasa, N. N. K., \& Setini, M. (2021). Comparative and competitives advantages: Perspective of rural tourism (Study on tourism in the province of Bali Indonesia). Geojournal of Tourism and Geosites, 33(4), 1493-1500. https://doi.org/10.30892/gtg.334spl07-598.

51. Xu, Z., Gao, X., Wang, Z., Gilroy, R., \& Wu, H. (2018). An investigation of non-localgoverned urban villages in China from the perspective of the administrative system. Habitat International, 74(February), 27-35. https://doi.org/10.1016/j.habitatint.2018.02.007.

52. Zhang, S. (2019). Public participation in the Geoweb era: Defining a typology for geoparticipation in local governments. Cities, 85(November 2018), 38-50. https://doi.org/10.1016/j.cities.2018.12.004. 